\title{
Sarcomeric mutations in cardiac diseases
}

\author{
Samantha P. Harris ${ }^{1}$ (D) P Pieter P. de Tombe ${ }^{2}$
}

Received: 26 March 2019 / Accepted: 1 April 2019 / Published online: 11 April 2019

(C) Springer-Verlag GmbH Germany, part of Springer Nature 2019

The ability of mutations in genes encoding cardiac proteins to cause disease was first described nearly 30 years ago when Geisterfer-Lowrance et al. [5] traced the inheritance of hypertrophic cardiomyopathy (HCM) in a large family to a single missense mutation in $M Y H 7$, the gene encoding myosin. Since that time hundreds of additional mutations in myosin, myosin regulatory proteins, and other proteins, mostly associated with cardiac sarcomeres (the force generating units of muscle), have been identified as causative in clinical cardiomyopathies such as HCM and dilated cardiomyopathy (DCM) $[8,11,17]$. Intense research efforts over the past 3 decades have thus been aimed at understanding the impact of each of these mutations at the molecular level in order to translate "molecular" phenotypes into accurate predictions of patient disease phenotypes.

The problem is that despite the logic in assuming a unique genotype-phenotype relationship for each mutation and the clear clinical urgency of solving such relationships, it has proven extremely challenging to predict patient phenotypes from genotypes alone. This is because even for family members with the same mutation clinical outcomes can and do vary greatly-from completely asymptomatic throughout the lifetime of an individual to heart failure or sudden cardiac death at an early age $[15,16]$. The situation is compounded further when considering that hundreds of different mutations occur in a myriad of proteins, each presumably resulting in distinct molecular and patient phenotypes. As one example, two different mutations that affect the same residue in troponin $\mathrm{T}$

Samantha P. Harris

samharris@email.arizona.edu

Pieter P. de Tombe

pdetombe@uic.edu

1 Department of Cellular and Molecular Medicine, College of Medicine, University of Arizona, Tucson, AZ 85724, USA

2 Department of Physiology and Biophysics, College of Medicine, University of Illinois, 835 S. Wolcott Rm E202 (MC901), Chicago, IL 60612-7342, USA
(R92L and R92W) lead to divergent phenotypes [10]. However, the converse is also often true and presents an equally challenging paradox: How can different mutations in different proteins ultimately activate similar pathways that lead to the classical descriptions of HCM or DCM?

Most attempts to crack the genotype-phenotype conundrum thus far have adopted the strategy of looking for similarities in molecular phenotypes that correlate with clinical phenotypes. For instance, an early observation was that mutations causing $\mathrm{HCM}$ are often associated with an increase in myofilament $\mathrm{Ca}^{2+}$ sensitivity of tension (resulting in more force at a given level of $\mathrm{Ca}^{2+}$ ), whereas mutations associated with DCM often lead to a decrease in $\mathrm{Ca}^{2+}$ sensitivity of tension [4]. Because an increase in $\mathrm{Ca}^{2+}$ sensitivity of tension can account for slowed relaxation as well as the preserved (or even hyper-contractile) systolic function often seen in HCM patients, the hypothesis is attractive both for its simplicity and because it is suggestive of therapeutic remedies that target $\mathrm{Ca}^{2+}$ sensitivity $[1,2]$. Nonetheless such generalizations are not universal $[3,7,10]$ and are likely to be over-simplifications that lack the sensitivity or specificity necessary for predicting individual patient disease burden. Clearly, despite the enormous progress made in identifying the root genetic causes of cardiomyopathies, there is still much more to learn regarding if, when, and how a given mutation will impact patient lives.

In this Special Issue of Pflugers Archiv, European Journal of Physiology, we invited experts and world leaders in genetic cardiomyopathy research to contribute concise reviews on the current status of knowledge in their fields. Review topics focus on commonly affected proteins such as myosin, cardiac myosin binding protein-C (cMyBP-C), myosin light chains, titin, and thin filament proteins as well as new players such as the obscurin family of proteins. Additional topics include approaches for integrative disease modeling that leverage computational methods or iPSC-derived cardiomyocytes, novel veterinary animal models, and updates on the quest for therapeutic strategies. Importantly, reviews also include emerging concepts that go beyond effects of a single mutation, for instance many mutations in myosin and cMyBP-C may share 
common functional effects that disrupt the relaxed state of the thick filament $[12,14]$. Cellular and organ level functions are also considered as it is increasingly recognized that processes downstream of the genetic mutation such as transcription, protein quality control mechanisms and microvasculature dysfunction are factors that can significantly impact disease progression. For instance, cell-to-cell variability in expression of mutant and wild-type alleles may lead to contractile imbalances at the tissue level that either initiate or exacerbate pathological remodeling $[9,13]$. If so, then allelic imbalances observed in myocardial samples from HCM patients may well correlate with disease progression or severity [6]. Taken in aggregate, the review articles in this Special Issue provide updates on current and emerging topics that will undoubtedly bring us closer to deciphering complex genotype-phenotype relationships and to identifying effective therapeutic options for cardiac diseases caused by genetic mutations.

\section{References}

1. Alves ML, Dias FAL, Gaffin RD, Simon JN, Montminy EM, Biesiadecki BJ, Hinken AC, Warren CM, Utter MS, Davis RT, Sakthivel S, Robbins J, Wieczorek DF, Solaro RJ, Wolska BM (2014) Desensitization of myofilaments to $\mathrm{Ca} 2+$ as a therapeutic target for hypertrophic cardiomyopathy with mutations in thin filament proteins. Circ Cardiovasc Genet 7:132-143. https://doi.org/ 10.1161/CIRCGENETICS.113.000324

2. Alves ML, Warren CM, Simon JN, Gaffin RD, Montminy EM, Wieczorek DF, Solaro RJ, Wolska BM (2017) Early sensitization of myofilaments to $\mathrm{Ca} 2+$ prevents genetically linked dilated cardiomyopathy in mice. Cardiovasc Res 113:915-925. https://doi.org/ 10.1093/cvr/cvx068

3. Dweck D, Hus N, Potter JD (2008) Challenging current paradigms related to cardiomyopathies. Are changes in the $\mathrm{Ca} 2+$ sensitivity of myofilaments containing cardiac troponin C mutations (G159D and L29Q) good predictors of the phenotypic outcomes? J Biol Chem 283:33119-33128. https://doi.org/10.1074/jbc.M804070200

4. Fatkin D, Graham RM (2002) Molecular mechanisms of inherited cardiomyopathies. Physiol Rev 82:945-980. https://doi.org/10. 1152/physrev.00012.2002

5. Geisterfer-Lowrance AA, Kass S, Tanigawa G, Vosberg HP, McKenna W, Seidman CE, Seidman JG (1990) A molecular basis for familial hypertrophic cardiomyopathy: a beta cardiac myosin heavy chain gene missense mutation. Cell 62:999-1006

6. Helms AS, Davis FM, Coleman D, Bartolone SN, Glazier AA, Pagani F, Yob JM, Sadayappan S, Pedersen E, Lyons R, Westfall MV, Jones R, Russell MW, Day SM (2014) Sarcomere mutationspecific expression patterns in human hypertrophic cardiomyopathy. Circ Cardiovasc Genet 7:434-443. https://doi.org/10.1161/ CIRCGENETICS.113.000448

7. Helms AS, Alvarado FJ, Yob J, Tang VT, Pagani F, Russell MW, Valdivia HH, Day SM (2016) Genotype-dependent and independent calcium signaling dysregulation in human hypertrophic cardiomyopathy. Circulation 134:1738-1748. https:// doi.org/10.1161/CIRCULATIONAHA.115.020086

8. Ingles J, Goldstein J, Thaxton C, Caleshu C, Corty EW, Crowley SB, Dougherty K, Harrison SM, McGlaughon J, Milko LV, Morales A, Seifert BA, Strande N, Thomson K, Peter van Tintelen J, Wallace K, Walsh R, Wells Q, Whiffin N, Witkowski L, Semsarian C, Ware JS, Hershberger RE, Funke B (2019) Evaluating the clinical validity of hypertrophic cardiomyopathy genes. Circ Genom Precis Med 12:e002460. https://doi.org/10. 1161/CIRCGEN.119.002460

9. Kraft T, Montag J, Radocaj A, Brenner B (2016) Hypertrophic cardiomyopathy: cell-to-cell imbalance in gene expression and contraction force as trigger for disease phenotype development. Circ Res 119:992-995. https://doi.org/10.1161/CIRCRESAHA.116. 309804

10. Lehman SJ, Tal-Grinspan L, Lynn ML, Strom J, Benitez GE, Anderson ME, Tardiff JC (2019) Chronic calmodulin-kinase II activation drives disease progression in mutation-specific hypertrophic cardiomyopathy. Circulation 139:1517-1529. https://doi.org/ 10.1161/CIRCULATIONAHA.118.034549

11. McNally EM, Mestroni L (2017) Dilated cardiomyopathy: genetic determinants and mechanisms. Circ Res 121:731-748. https://doi. org/10.1161/CIRCRESAHA.116.309396

12. McNamara JW, Li A, Lal S, Bos JM, Harris SP, van der Velden J, Ackerman MJ, Cooke R, Remedios Dos CG (2017) MYBPC3 mutations are associated with a reduced super-relaxed state in patients with hypertrophic cardiomyopathy. PLoS One 12:e0180064. https://doi.org/10.1371/journal.pone.0180064

13. Montag J, Kowalski K, Makul M, Ernstberger P, Radocaj A, Beck J, Becker E, Tripathi S, Keyser B, Mühlfeld C, Wissel K, Pich A, van der Velden J, Remedios Dos CG, Perrot A, Francino A, Navarro-López F, Brenner B, Kraft T (2018) Burst-like transcription of mutant and wildtype $\mathrm{MYH} 7$-alleles as possible origin of cell-to-cell contractile imbalance in hypertrophic cardiomyopathy. Front Physiol 9:359. https://doi.org/10.3389/fphys.2018.00359

14. Nag S, Trivedi DV, Sarkar SS, Adhikari AS, Sunitha MS, Sutton S, Ruppel KM, Spudich JA (2017) The myosin mesa and the basis of hypercontractility caused by hypertrophic cardiomyopathy mutations. Nat Struct Mol Biol 24:525-533. https://doi.org/10.1038/ nsmb.3408

15. Tardiff JC (2017) Assessing the phenotypic burden of preclinical sarcomeric hypertrophic cardiomyopathy-new assessments to guide diagnosis and management. JAMA Cardiol 2:428-429. https://doi. org/10.1001/jamacardio.2016.5677

16. van der Velden J, Ho CY, Tardiff JC, Olivotto I, Knollmann BC, Carrier L (2015) Research priorities in sarcomeric cardiomyopathies. Cardiovasc Res 105:449-456. https://doi.org/10.1093/cvr/ cvv019

17. Walsh R, Mazzarotto F, Whiffin N, Buchan R, Midwinter W, Wilk A, Li N, Felkin L, Ingold N, Govind R, Ahmad M, Mazaika E, Allouba M, Zhang X, de Marvao A, Day SM, Ashley E, Colan SD, Michels M, Pereira AC, Jacoby D, Ho CY, Thomson KL, Watkins H, Barton PJR, Olivotto I, Cook SA, Ware JS (2019) Quantitative approaches to variant classification increase the yield and precision of genetic testing in Mendelian diseases: the case of hypertrophic cardiomyopathy. Genome Med 11:5. https://doi.org/10.1186/ s13073-019-0616-z

Publisher's note Springer Nature remains neutral with regard to jurisdictional claims in published maps and institutional affiliations. 